\title{
Arduino alapú mozgásvezérelt kamerasín rendszer tervezése \& vezérlése Android eszközzel
}

\author{
Balázs József Bence \\ Debreceni Egyetem, \\ Informatikai Kar \\ Debrecen, Magyarország \\ balazsjobence@gmail.com
}

\author{
Darai Gyula Attila \\ Mechatronikai Tanszék \\ Debreceni Egyetem, Müszaki Kar \\ Debrecen, Magyarország \\ darai@eng.unideb.hu
}

\author{
Erdei Timotei István \\ Mechatronikai Tanszék \\ Debreceni Egyetem, Müszaki Kar \\ Debrecen, Magyarország \\ timoteierdei@eng.unideb.hu
}

\begin{abstract}
Absztrakt_A digitális tükörreflexes fényképezőgépek megjelenésével, a filmezés történelmében mindig is jelenlévő technológiai és pénzügyi határvonal a meghatározó produkciós szereplők és amatőr filmkészítők között folyamatosan mosódik el. Ennek hatására új filmipari szegmens jött létre, melynek célja, hogy az elérhető áru kameramozgató/stabilizáló tartozékok és kiegészítők iránti növekvő igényt kielégítse, valamint lépést tartson a XXI. századi modern filmkészítés felmerüló kihívásaival, mely könnyen hordozható, egyszerüen programozható és felügyelet nélkül automatizálható rendszereket követel meg.

Projektemben egy olyan mozgásvezérelt kamerasín rendszer került megtervezésre és megépítésre, mely a fent említett kívánalmaknak megfelelve biztosít egy Arduino alapon programozható lehetőséget produkciós stúdiók számára.
\end{abstract}

Kulcsszavak-Arduino; mozgásvezérlés; filmipar; okostelefon; kameramozgatás; automatizálás, PLC

\section{BEVEZETÖ}

Mai világunkban az információs technológia fejlődése életünk egyre több aspektusát határozza meg növekvő tempóban. Hasonlóképpen a filmes ipar haladási irányát is befolyásolja, mely több mint száz éves történelme során mindig is nyitott volt az újonnan megjelenő trendek és innovatív elképzelések hatékony adaptálására és használatára [1][2]. Továbbá az új rendszerek az oktatás színvonalának elősegítéséhez is hozzájárulhatnak [16]. Az automatizálási technikáknál megfigyelhető gyors fejlődés új lehetőségeket nyit meg a PLC programozás terén [17]. Az IoT rendszerek innovatív alkalmazásai is kulcsfontosságúak lesznek a közeljövőben [18].

A mozgásvezérlés a fotográfia és a mozgóképrögzítés egy olyan technikája, amely precíz és előre meghatározott, valamint tökéletes pontossággal, bárhányszor megismételhető kameramozgatást tesz lehetővé [20].

Egyik első képviselője a Dykstraflex [3] nevü eszköz volt, melyet kimondottan az 1976-ban forgatott Star Wars kultikus című film munkálataihoz készítettek.

Több, mint negyven év alatt ugyan kiforrottabbá és elterjedtebbé vált a technológia, ám a számos próbálkozás ellenére is csak nehezen megfizethető vagy alapvetö szükségleteket nélkülöző mozgásvezérelt rendszerek kerültek elérhető kategóriába az egyedülálló filmkészítők és a kisvállalkozásként operáló produkciós irodák számára [4].

Ennek a hiánynak a kiküszöbölése érdekében került megalkotásra e projekt keretein belül, egy valós forgatási körülmények között is helytálló, ennek ellenére egyszerüen kezelhető és megbízható, automatizálható kameramozgató rendszer.

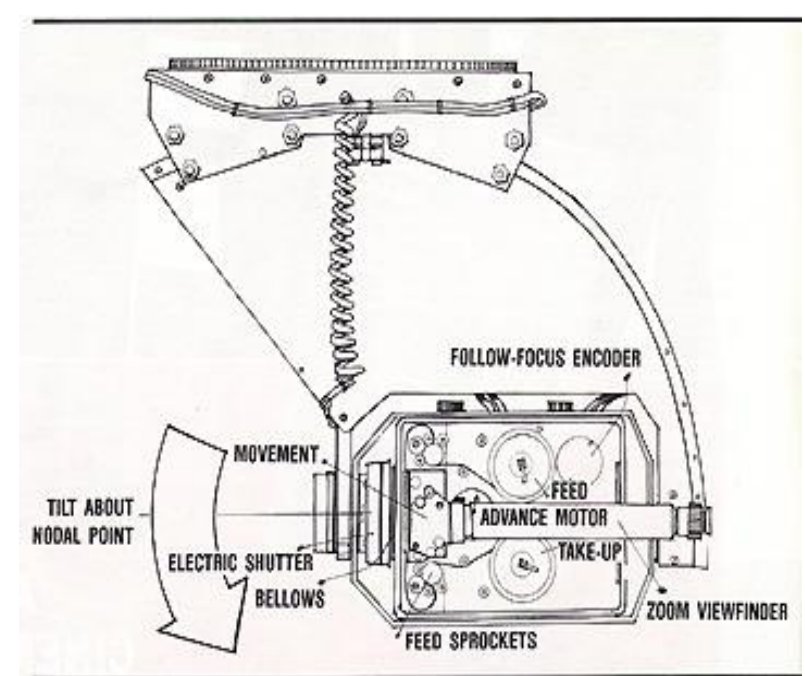

1. ábra: Dykstraflex mozgásirányított kameramozgató eszköz [15]

\section{TERVEZÉSI SZEMPONTOK}

Egy mozgásvezérelt kamerasín használatát igénylő forgatási nap során a stáb több tucat különböző helyszínen fordul meg, ezért szükséges egy olyan eszköz, amely felállítása percek alatt megtörténhet és utána felügyelet nélkül tudja végezni a rá kiszabott feladatot. így nem csak értékes időt spórol, de még értékesebb emberi erőt is felszabadít, akik így más tevékenységet tudnak végezni [5].

A tervezés egyik fontos szempontja volt, hogy a rendszer Arduino alapú legyen a sokoldalúság és a későbbi bővíthetőség érdekében [19], továbbá vezeték nélkül legyen képes okostelefonnal kommunikálni, azért, hogy a helyszínen való beprogramozás ne igényeljen speciális eszközt. Ezáltal a forgatási csapat bármelyik tagja egy nála lévő Android vagy iOS rendszerü telefonnal is be tudja állítani a kamerasínt. 
A projekt a későbbi bővíthetőség figyelembe vételével készült, ezért mérvadó volt, hogy a sínhez szükséges hardver könnyen elérhetö legyen. Az Open Source Hardware [6] lényege, hogy a különböző hardverelemek terveit bárki tanulmányozhatja, felhasználhatja, illetve átalakíthatja. Az Openbuilds[7] által gyártott és forgalmazott extrudált alumínium profil, a V-Slot biztosítja, hogy a rendszert könnyedén lehessen bővíteni kompatibilis alkatrészekkel.

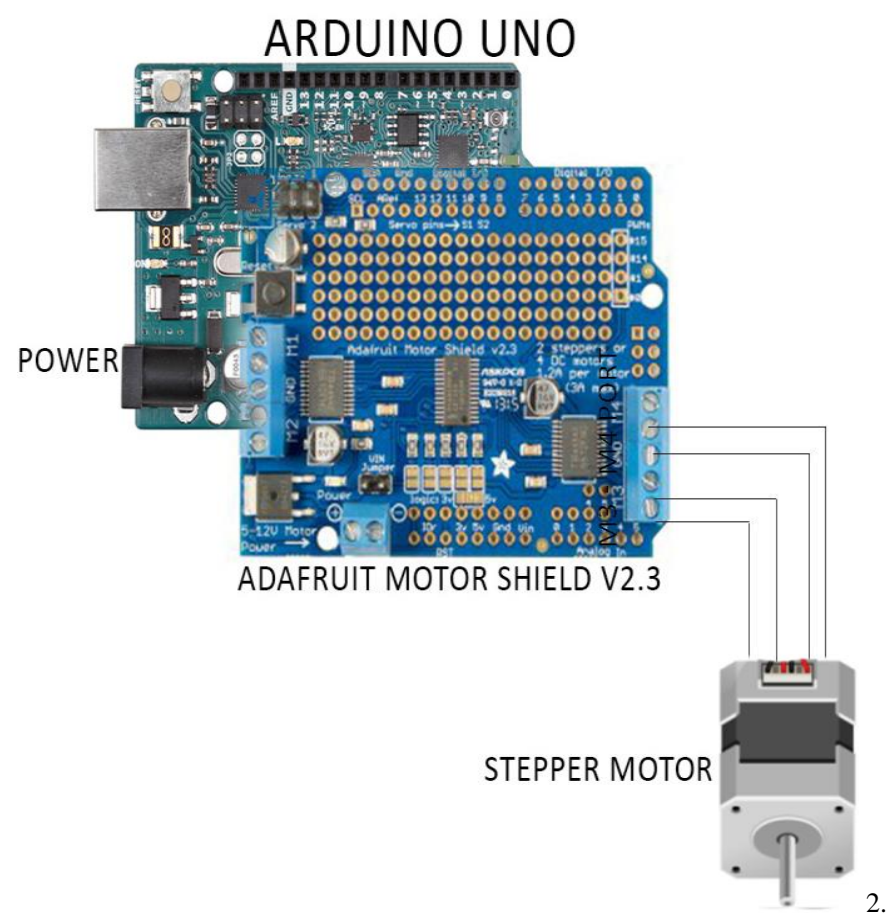

ábra: Az áramkör alapvető felépítése

\section{FELHASZNÁLT HARDVER ÉS SZOFTVER}

A sín föbb alkotóelemei egy 600 × 20 × 40 mm méretü Openbuilds V-Slot extrudált alumíniumrúd, hozzátartozó dupla golyóscsapágyas, delrin műanyag bevonatú $\mathrm{V}$ Wheel kerekek, állítható magasságú alumínium lábak és egy alumínium állványlemez.

A pontosság érdekében egy NEMA 17 [8] típusú bipoláris hibrid léptetőmotor került beépítésre.

A projekt jellegéből adódóan szükséges volt, hogy léptetőmotor biztosítsa a meghajtást, mivel nagy pontossággal lehet vezérelni, illetve jó ár-érték aránnyal rendelkezik, ami minden produkció esetében elsődleges szempont. A NEMA 17 képes a nagyon apró, akár 1.8 fokos léptékkel haladni.

A motor méretei 48 x 42 x $42 \mathrm{~mm}$. A projekt fó része az Arduino UNO WIFI panel, amely egy Adafruit Motor Shield v2.3 típusú léptetőmotor vezérlő modulon keresztül irányítja a kamerasínt.

A vezérlőszoftver kidolgozása egy Intel(R) Core(TM) i74790 @ 3.50GHZ CPU-val, 32GB DDR3 1600 MHZ memóriával és egy Asus GeForce GTX 960 videokártyával felszerelt asztali számítógépen történt Windows 8.1 Home operációs rendszer alatt, Arduino IDE fejlesztői környezetben.
Az okostelefonon keresztül történő irányításhoz a Blynk IoT alkalmazás könyvtára került implementálásra.

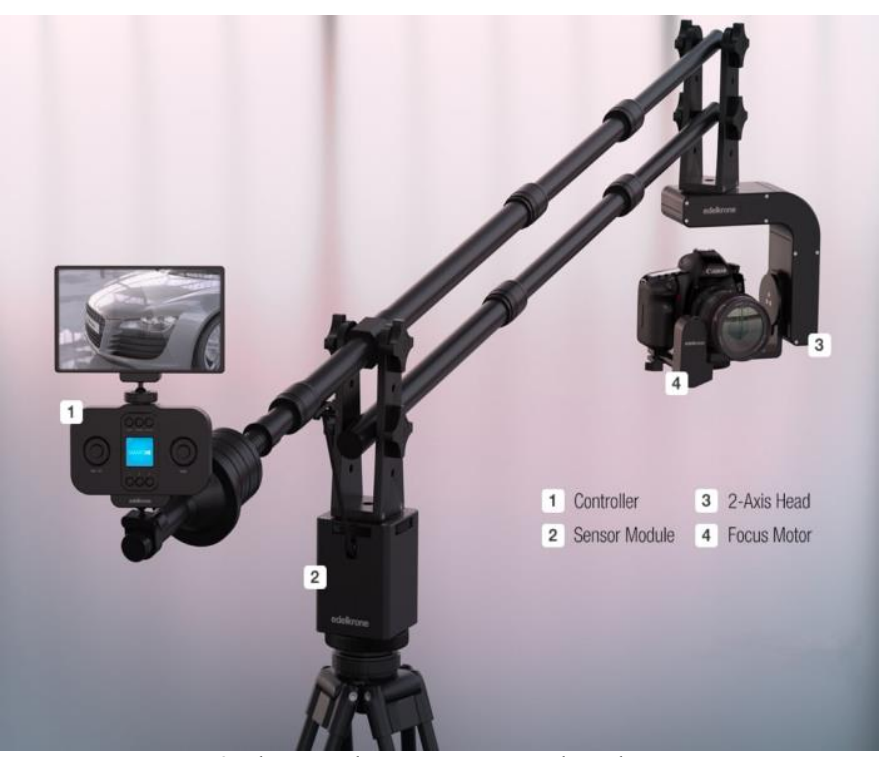

3. ábra: Modern mozgásvezérelt eszköz

\section{ELKÉSZÜLT ÁRAMKÖR}

Az áramkör alapja Circuits.io-ban [9] került megtervezésre. A Circuit.io egy online felület, ami lehetővé teszi az elektronikai áramkörök megtervezését és tesztelését is.

Az áramkör fó alkotóeleme az Arduino UNO WIFI panel, ami az Adafruit Motor Shield v2.3 motorvezérlő modulon keresztül kommunikál a NEMA 17 léptetőmotorral 


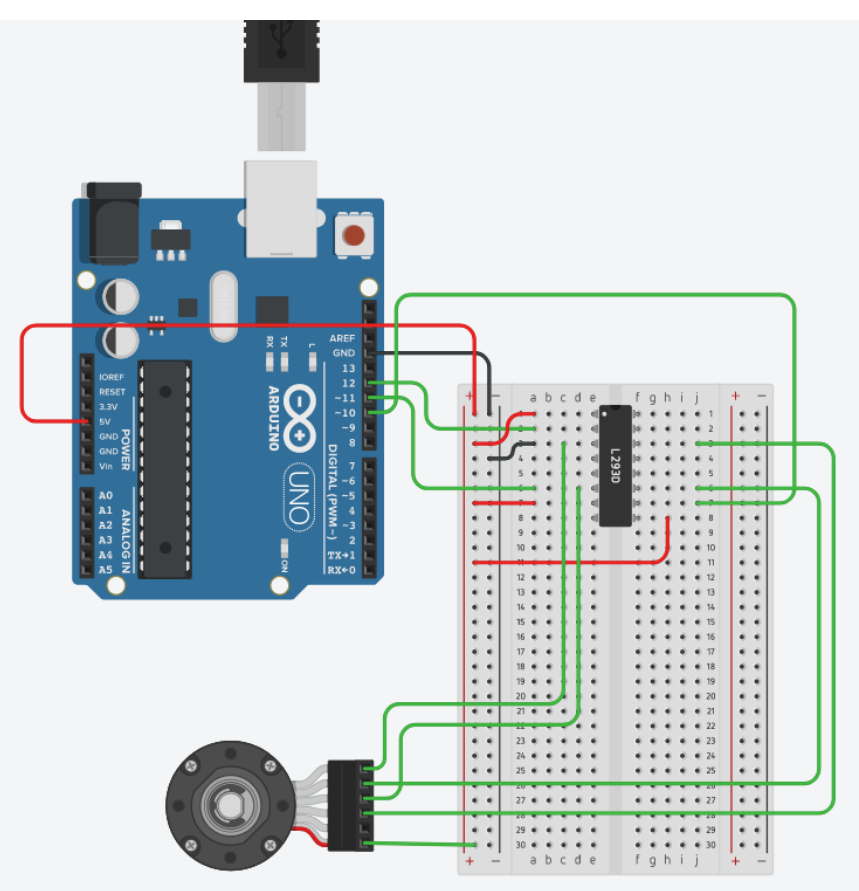

4. ábra: Circuit.io előzetes tervezés

Az Arduino [10] egy open-source platform elektronikai projektek számára. Egy programozható áramköri lapból áll, illetve a hozzátartozó Arduino IDE nevü fejlesztői környezetből. A választás az Arduino UNO WIFI panelre esett, mivel a 14 digitális és 6 analóg tüje és az USB kapcsolat mellett integrált $\mathrm{Wi}-\mathrm{Fi}$ modullal is rendelkezik. A panel az Atmega328P mikrokontrollerre és az ESP8266 Wi-fi modulra épül. Az ESP8266 modul egy önálló egylapkás rendszer integrált TCP/IP protokollkészlettel. Segítségével külön hardver nélkül kapcsolódhat a mozgásvezérlő eszköz a hálózathoz, ezáltal az okostelefonokhoz is.

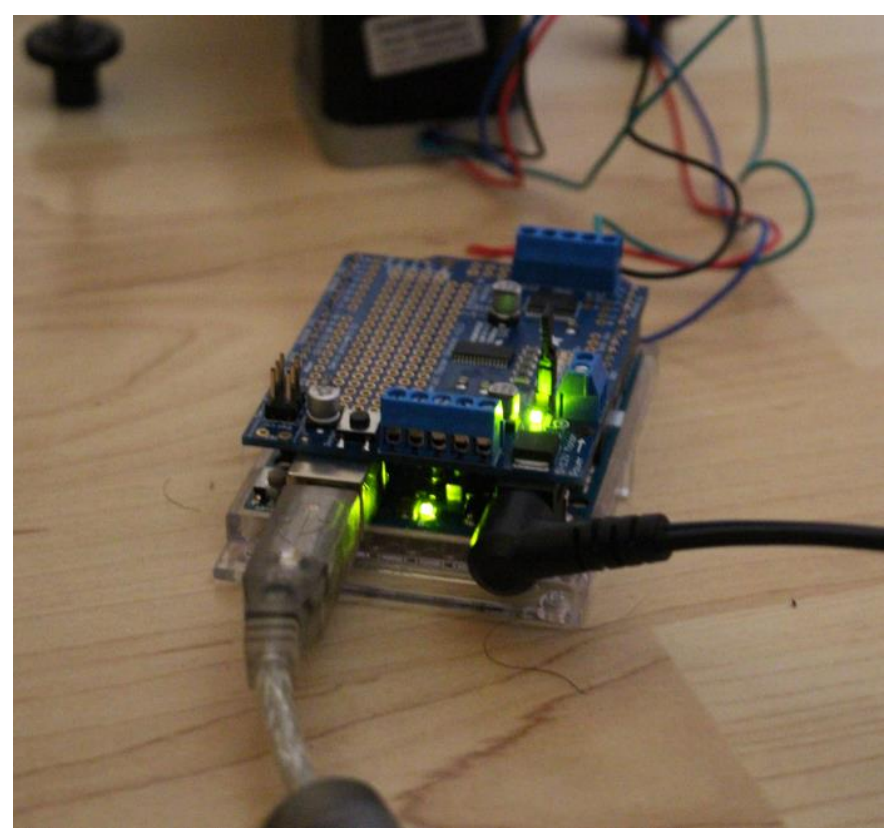

5. ábra: Adafruit Motor Shield v2.3 és az Arduino UNO Wi-Fi
Az Adafruit Motor Shield v2.3 [11] motor vezérlő modul az Adafruit cég terméke. Az online magazinként induló vállalatot egy Massachusetts Institute of Technology intézményen tanuló mérnök hallgató alapította 2005-ben azzal a vízióval, hogy létrehozzon egy online közösséget, ahol bárki felfrissítheti és tovább képezheti az elektronikai ismereteit. A nagy sikerü eredeti Adafruit Motorshield készlet továbbfejlesztett változata az Adafruit Motor Shield v2.3. A modul képes 4 darab DC vagy 2 darab léptetőmotor egyidejü müködtetésére, valamint akár 34 vezérlö modul egymásra halmozására, így akár 128 darab DC, illetve 64 darab léptetőmotor irányítható. Fedélzeti dedikált PWM drivert használ az Arduino saját PWM tüi helyett. További nagy előnye a saját Arduino szoftverkönyvtár is. Mivel lehetővé teszi további léptetőmotorok hozzáadását, így tökéletess választásnak bizonyult a projekthez, hogy a bővíthetőség lehetősége megmaradjon.

\section{A PROGRAMOZÁSI KÖRNYEZET}

A program, amely az egész rendszert vezérli, Arduino IDE fejlesztői környezetben került megírásra. Ez egy open-source szoftver, mely egy szövegszerkesztőt tartalmaz a kód írásához, egy üzenetmező, egy szöveges konzol és egy eszközsor mellett. Az itt született programokat Vázlatoknak hívjuk, melyek USB kapcsolaton keresztül vagy OTA (Over-The-Air) [12], azaz vezeték nélküli kapcsolaton keresztül jutnak el az adott áramköri lapra.

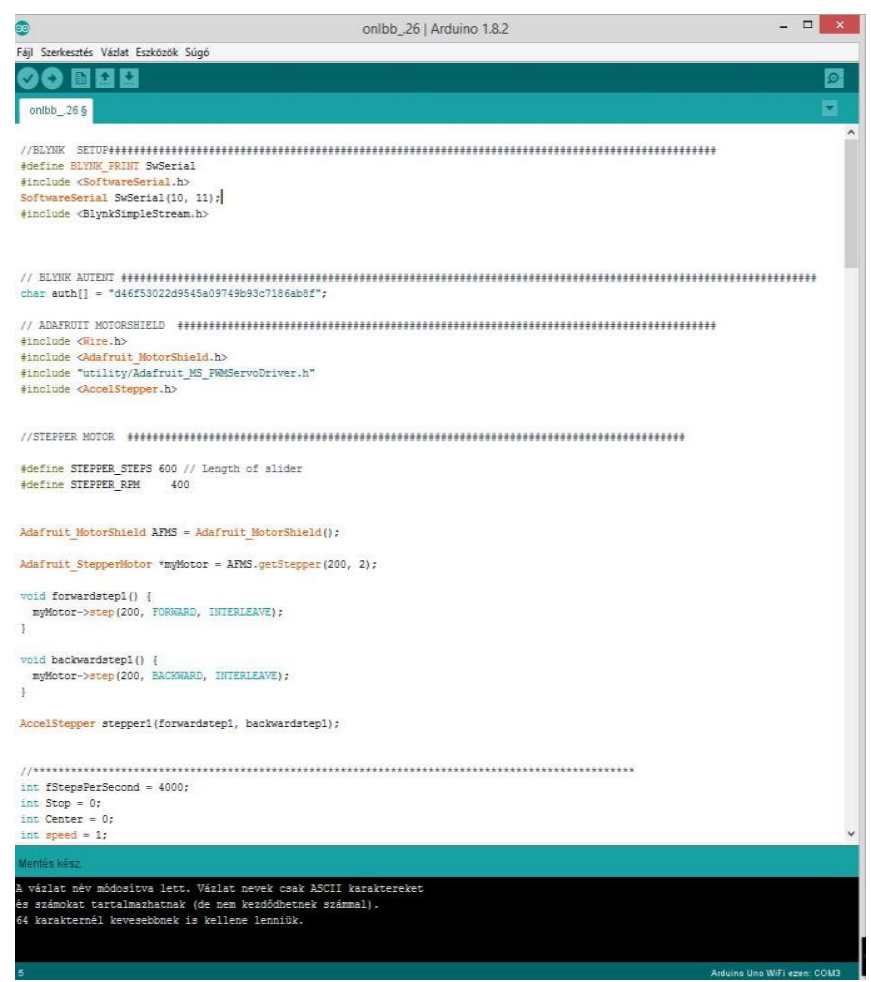

6. ábra: Arduino IDE

Az Arduino vázlatok a $\mathrm{C}++$ nyelv egy változatán íródnak. Minden vázlat tartalmaz egy setup() és egy loop() függvényt. A setup() függvény pontosan egyszer fut le, rögtön az Arduino 
lapka beindítása után, és inicializálásra használandó, ezután a loop() függvény fut folyamatosan újra és újra. Az áramköri lapon található ki- és bemeneti tük elemi részét képezik a programozásnak.

I. Táblázat: Adafruit Motor Shield V2.3 léptetési típusok

\begin{tabular}{|c|c|c|}
\hline & Típus & Tulajdonság \\
\hline 1. & Single & egytekercses \\
\hline 2. & Double & 2 tekercs egyidejüleg \\
\hline 3. & Interleave & váltakozó \\
\hline 4. & Microstep & PWM \\
\hline
\end{tabular}

VI. A PROGRAM MÜKÖDÉSE

A mozgásvezérlő programhoz szükségünk van különböző könyvtár állományok meghívására.

Először a vezeték nélküli okostelefonhoz való kapcsolódást lehetővé tévő Blynk könyvtár került hozzáadásra. A Blynk [13] egy olyan IoT applikáció, mely különféle hardverek távirányítását teszi lehetővé. Ezen kívül a hozzá tartozó program képes közvetlenül elérni a kívánt tüket, továbbá virtuális tüket is biztosít. Segítségével képesek vagyunk megosztani a programhoz való közvetlen hozzáférést, így megkönnyítve a valós körülmények között történő munkát.

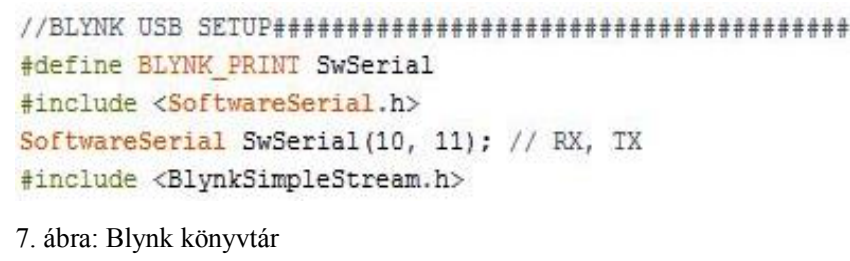

További könyvtárként az Adafruit Motor Shield v2.3 Adafruit_Motorshield.h és az Accelstepper.h került hozzáadásra, melyek a léptetőmotor kezeléséhez kapcsolódó függvényeket tárolják. A létrehozott léptetőmotor objektum megadott paraméterei 200 lépés fordulatonként, ami szükséges, hogy a motor egy teljes fordulatot tegyen 1.8 fokonkénti elfordulással, illetve, hogy a 2-es számú porton kapcsolódik a modulhoz.

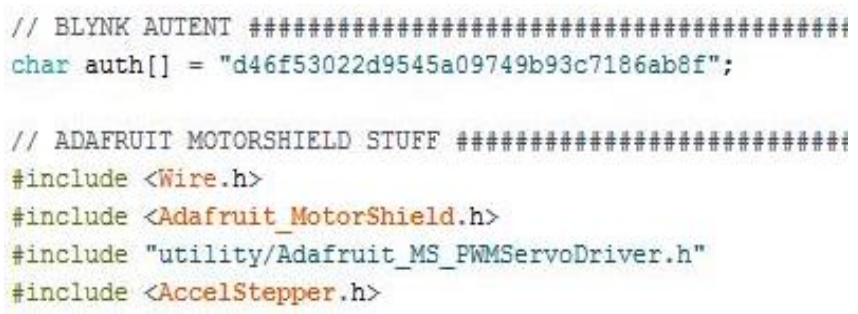

A motorvezérlő több lehetséges léptetési módot tesz lehetővé: „Single”, vagyis egytekercses, „Double”, vagyis egy időben két tekercs aktiválódik a nagyobb forgatónyomaték érdekében, „Interleave”, vagyis az előző két mód között váltakozik a nagyobb felbontás érdekében, illetve „Microstepping”, vagyis az a metódus, amikor impulzusszélesség-modulációval
(PWM) sima mozgást biztosít a lépések között. A program legtöbb esetben az Interleave módot alkalmazza.

Az Accelstepper.h könyvtár függvényeinek a müködéséhez és egy Accelstepper [14] léptetőmotor objektum létrehozásához szükséges az elöre- és hátramenetet biztosító függvények „becsomagolása”.

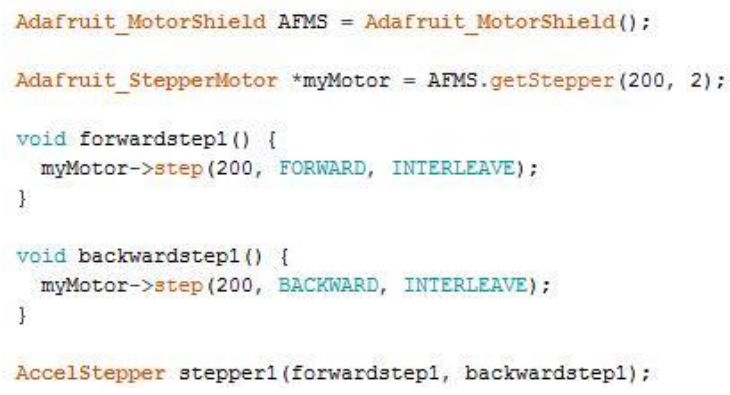

9. ábra: Adafruit léptetőmotor és Accelstepper objektumok

A setup() részben meghatározzuk a motor maximális sebességét és maximális gyorsulását. A pontos értékek beállításához szükség volt több körös tesztelésre kamera terhelése nélkül, és kamera terhelésével is. Az így kapott eredményekkel a motor sima mozgással indul, hogy felgyorsulhasson a megadott sebességre, miközben nem okoz vibrálást vagy rázkódást, így meghiúsítva az adott felvételt.

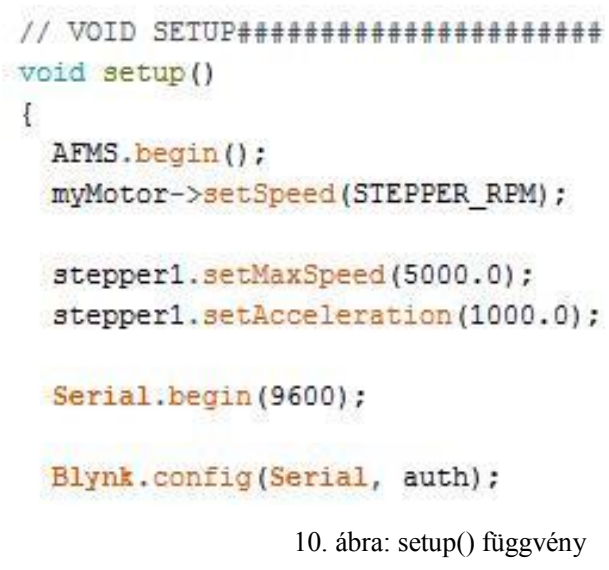

A különböző funkciók vezetéknélküli vezérléséhez egyegy virtuális tü került hozzáadásra. Ezek az okostelefonon futó applikációban létrehozott input eszközökhöz: gombok, csúszkák, kapcsolók, terminálhoz csatlakoznak.

$\mathrm{Az}$ első funkció alapszintű mozgatást tesz lehetővé gombnyomásra, hogy a kamerát a kívánt kezdő vagy végpozícióba juttathassuk. 


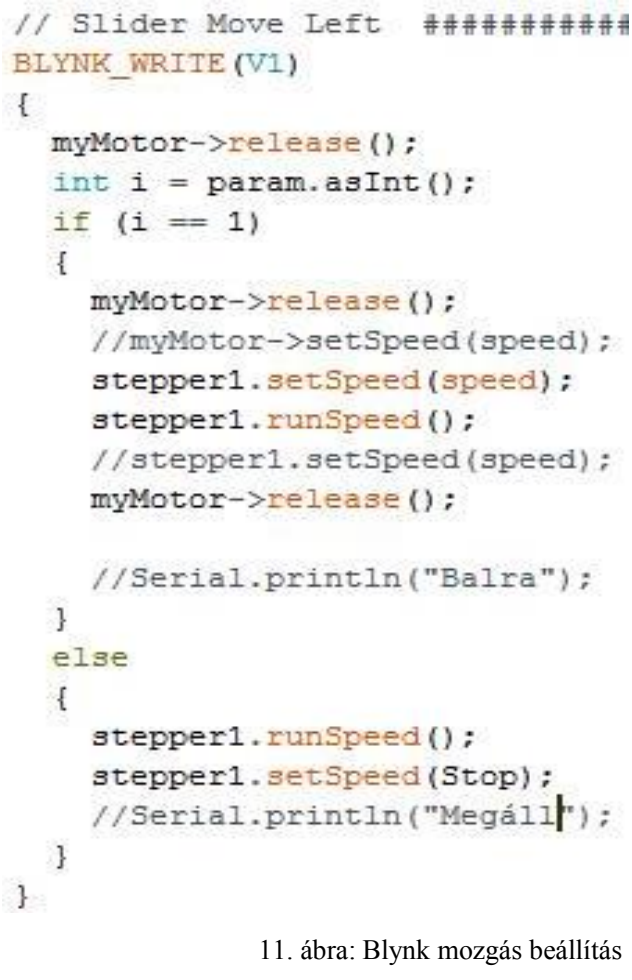

\section{1. ábra: Blynk mozgás beállítás}

Egy csúszkával gyorsan beállíthatjuk a motor kívánt sebességét, amit akár menet közben is lehet változtatni, hiszen a program folyamatosan frissíti a sebességszabályzó változókat. Mivel léptetőmotorról van szó, így a motor jelenlegi helyzetét eltárolva vissza is tudunk térni hozzá. Gombnyomásra aktiválódik a program azon része, amellyel lehetőség nyílik megadni a kezdő- és végpontokat. Ezeket a gombok újbóli lenyomásáig tárolja. Egy újabb csúszka mozdításával a kód megkapja az automatizáláshoz szükséges paramétert is, amely a korábban megadott pontok által behatárolt szakaszon ismétli pontosan ugyanazt a mozgást.

A felhasználási területe ennek a funkciónak igen sokrétü. A filmstúdiók az úgynevezett kompozitáláshoz használják a technikát, amikor is több, pontosan azonos kameramozgással készült felvételt rétegenként helyeznek egymásra.

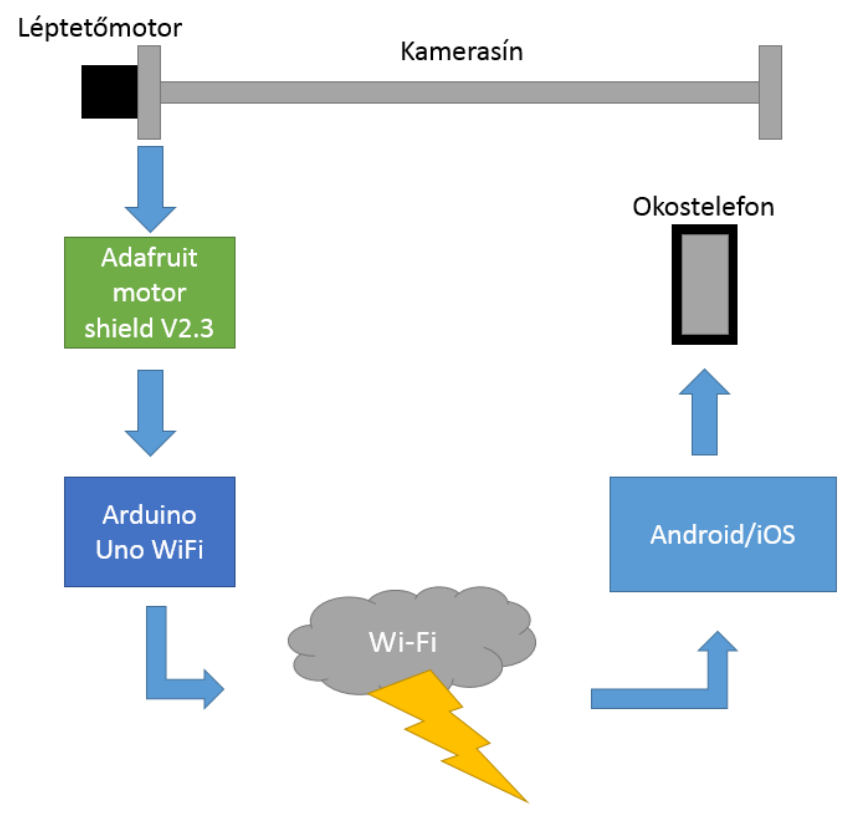

12. ábra: Vezeték nélküli vezérlés

A Timelapse funkció kihasználja a Microstep mód által rendelkezésre bocsátott sima mozgást. Ez lehetővé teszi az igazán kis léptékü mozdulatokat, így akár több óráig is tarthat, amíg a motor a megadott kezdőponttól a végéig ér. További fontos része a programnak, hogy minden lépés között megadott mennyiségű időn át várakozik, így a kamera akár hosszú záridejü fényképeket is készíthet.

\section{TESZTELÉS}

Az elkészült mozgásvezérelt kamerasínt valós forgatási körülmények közötti tesztelése elengedhetetlen volt ahhoz, hogy egy stáb megbízható eszközként tekintsen rá és képes legyen használni a sokszor elöre nem látható körülmények között is. Ezért a rendszert több féle helyzetben, stúdió körülmények között és kitelepült helyszínen is ellenőrizni kellett.

TABLE II. Helyszíni üzembe helyezési mérések

\begin{tabular}{|c|c|c|}
\hline & Idö (min:sec) & Helyszín \\
\hline 1. & $0: 46$ & Otthoni \\
\hline 2. & $0: 52$ & Stúdió \\
\hline 3. & $1: 37$ & kitelepült helyszín (belváros) \\
\hline 4. & $2: 01$ & kitelepült helyszín (külváros) \\
\hline
\end{tabular}

A mérések között föleg az üzembe helyezéshez szükséges idő mértékét kellett meghatározni. Ez a kamerasín kihelyezésétől, a vezeték nélküli kapcsolat felállításán és a beprogramozáson keresztül az adott feladat kezdőpillanatáig mért mennyiség. Az elvégzett mérésekböl arra lehet következtetni, hogy kontrollálható körülmények között (otthoni, stúdió) a felállítás és a kapcsolat kiépítése a leggyorsabb, míg kisebb lefedettségü területeken ez kimutathatóan több időbe telik. Mobilhálózaton való használat közben legalább $3 \mathrm{G}$ hálózati sebesség, vagyis minimum $2000 \mathrm{~Kb} / \mathrm{s}$ szükséges a zavartalan müködtetéshez. 
A legjobb teljesítményt LTE hálózaton, vagyis minimum 10 $\mathrm{Mb} / \mathrm{s}$ sebesség mellett érte el a rendszer.

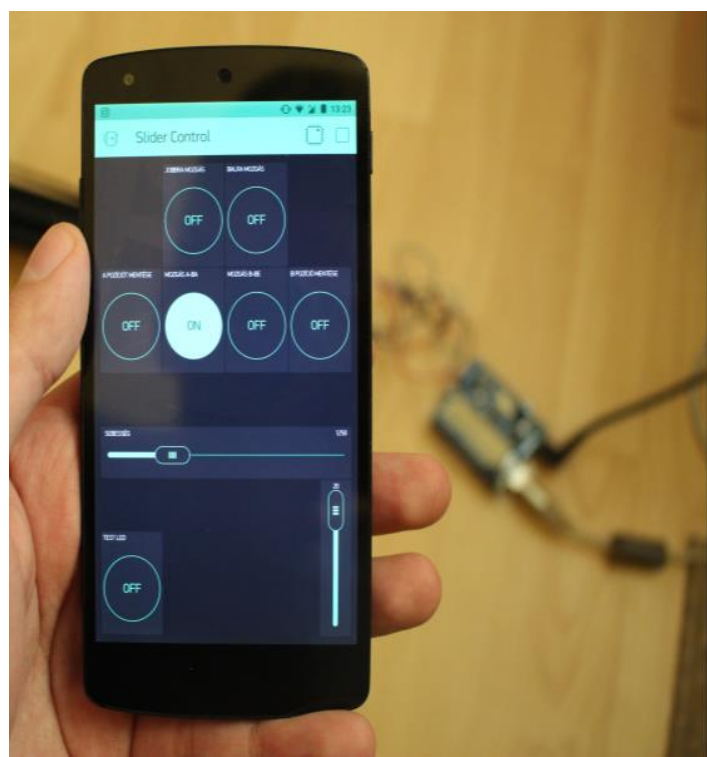

13. ábra: Vezeték nélküli irányítás Blynk felületen

\section{TOVÁBBI FEJLESZTÉSI LEHETŐSÉGEK}

$\mathrm{Az}$ elkészült rendszer egy kerek egészet alkotva képes ellátni feladatait, azonban van helye továbbfejlesztéseknek is. A jövőben további léptetőmotorok és motorvezérlő modulok adhatóak hozzá, így kiterjesztve a kamerasín jelenlegi képességeit akár több tengelyre is.

A kódban helyett kapott egy infravörös LED-et vezérlő részlet, mely képes a kamera zárszerkezetét adott időben működtetni. Infravörös LED hozzáadásával a kamera időzítése is megvalósulhat. Esetleges szükség felmerülése esetén az Arduino UNO Wi-Fi áramköri lap, valamint a léptetőmotorok cseréjével akár nagyobb tömegü kamerák is mozgathatóvá válhatnak.

\section{IX. ÖSSZEGZÉS}

Az Arduino alapú mozgásvezérelt kameramozgató rendszer megvalósításra került, mely képes a modern filmipari szükségleteket, vagyis a portabilitást, a könnyü programozhatóságot és a felügyelet nélküli működést kielégíteni, megfelelve ezzel a kisméretü produkciós irodák, illetve egyszemélyes filmkészítők igényeinek. Bővíthetőség szempontjából a rendszer készen áll, hogy további hardver hozzáadásával és a kód minimális kiegészítésével az üzembentartó gördülékenyen legyen képes felszerelni. A mérésekből következtetve megállapítható, hogy a rendszer alternatívát jelenthet az erősen behatárolt költségvetéssel dolgozó produkciók számára.

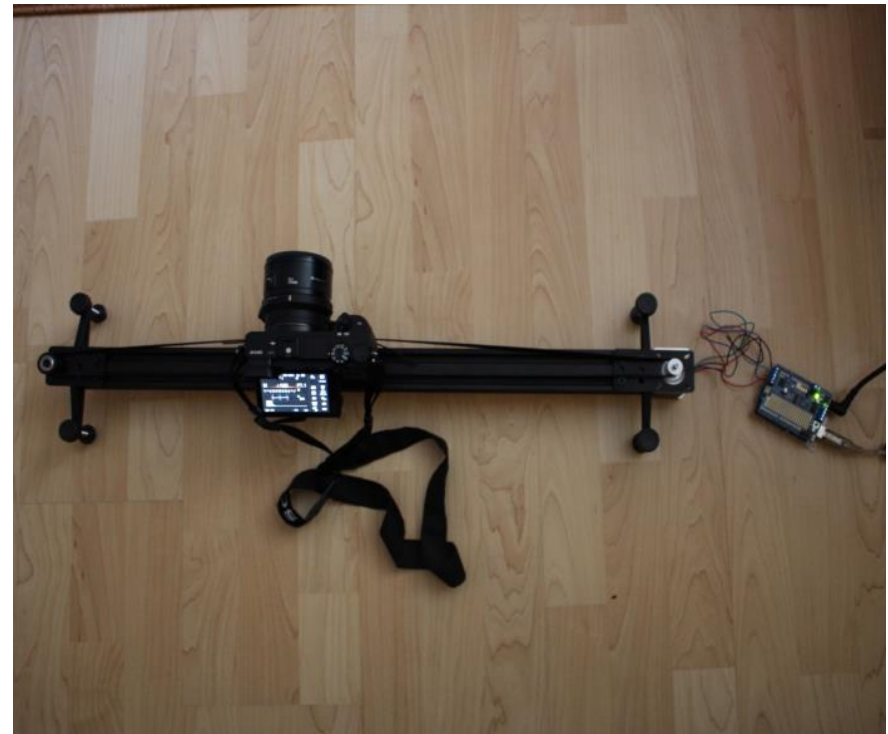

14. ábra: A rendszer müködés közben

\section{KÖSZÖNETNYILVÁNÍTÁS}

A publikáció elkészítését az EFOP-3.6.1-16-2016-00022 számú projekt támogatta. A projekt az Európai Unió támogatásával, az Európai Szociális Alap társfinanszírozásával valósult meg.

\section{HIVATKOZÁSOK}

[1] Andrew Reid, (2017.05.02.). The DSLR video revolution [Online]. Available: $\quad$ https://store.digitalrev.com/article/the-dslr-videorevolution/NTgyNA_A_A

[2] Slavik Boyechko, The DSLR Revolution: No Longer Just About the $\begin{array}{lll}\text { Camera } & \text { (2017.03.05.). Anline]. }\end{array}$ https://photography.tutsplus.com/articles/the-dslr-revolution-no-longerjust-about-the-camera--cms-22700

[3] William L. Weaver, Thinking in Pictures (2017.04.19). [Online]. Avalable: http://www.scientificcomputing.com/article/2011/11/thinkingpictures

[4] Advanced Motion Controls, (2017.03.03). [Online]. Available: https://www.a-m-c.com/history-of-motion-control/

[5] Robert Rodriguez, „Rebel Without a Crew”, 1996.

[6] What is open hardware?, (2017.03.20.). [Online]. Available: https://opensource.com/resources/what-open-hardware

[7] Openbuilds, (2017.03.20.), [Online]. Available: http://openbuildspartstore.com/about-us-2/

[8] Nema17 stepper motor manual, (2017.03.21.). [Online]. Available: http://www.nema17steppermotor.com/tags/reprap/

[9] John Biggs, (2017.03.30.). [Online]. Available: https://techcrunch.com/2013/09/10/autodesk-releases-an-electronicssimulator-called-123d-circuits/

[10] Arduino, (2017.04.05.). [Online]. Available: https://www.arduino.cc/

[11] Adafruit Motor Shield V2 for Arduino, (2017.04.05.). [Online]. Available: https://learn.adafruit.com/adafruit-motor-shield-v2-forarduino/overview

[12] Deepak Singh, (2017.05.01.). [Online]. Available: https://gadgetstouse.com/how-to-2/check-install-ota-update/8661

[13] Blynk, (2017.05.10.). [Online]. Available: http://www.blynk.cc

[14] Accelstepper, (2017.05.03.). [Online]. Available: http://www.airspayce.com/mikem/arduino/AccelStepper/ 
[15] Visual effects mechanical (2017.05.17). [Online] Available: https://www.flickeringmyth.com/2014/07/inventive-solutions-johndykstra-talks-art-creating-visual-effects/\#respond

[16] H. Géza, Gy. Darai, „Improving Education Quality By Using High Technology Devices," 14th Building Services, Mechanical and Building Industry Days. 462 p. Debrecen, Magyarország, 2008.10.30-2008.10.31. Debrecen: Debreceni Egyetem, 2008. pp. 356-365.

[17] Gergely E I, Husi G, Yildirim S, „PLC Programs Design Using Signal Interpreted Petri Networks," JOURNAL OF COMPUTER SCIENCE AND CONTROL SYSTEMS 2:(1) pp. 102-106. (2009)

[18] G. Husi, T. I. Erdei, Zs. Molnár, „A Novel Design of an Augmented Reality Based Navigation System \& its Industrial Applications," 15th
IMEKO TC10 - Technical Diagnostics in Cyber-Physical Era Budapest, Hungary, 6 - 7 June, 2017 - Organised by: MTA SZTAKI - Hungarian Academy of Sciences - Institute for Computer Science and Control

[19] Zs. Molnár, T. I. Erdei, A. Husam, G. Husi, „Self-developed CNC prototype as IoT device," FMTÜ - XXII. International Scientific Conference of Young Engineers - Kolozsvár, 23-24.03.2017.

[20] N. C. Obinna, T. I. Erdei, Zs. Molnár, G. Husi, „Investigating Configuration Space Singularities of KUKA KR5,"International Mechatronical Student micro-Conference IMS $\mu C^{\prime} 2016$. 